\title{
KEWENANGAN NOTARIS DALAM MEMBUAT AKTA PERNYATAAN TERKAIT RAPAT UMUM PEMEGANG SAHAM (RUPS) DAN PERTANGGUNGJAWABAN PIDANANYA (STUDI KASUS: PUTUSAN PENGADILAN TINGGI BANTEN NOMOR 9/PID/2019/PT. BTN)
}

\author{
SRI WAHYUNI \\ Universitas Pancasila \\ swahvuni1288@gmail.com
}

\begin{abstract}
ABSTRAK
Perubahan anggaran dasar Perseroan Terbatas ditetapkan oleh Rapat Umum Pemegang Saham dan dimuat atau dinyatakan dalam akta Notaris (Pasal 19 ayat (1) dan Pasal 21 ayat (4) Undang-Undang Perseroan Terbatas). Notaris dalam membuat akta terkait perubahan anggaran dasar suatu Perseroan seharusnya mematuhi ketentuan Undang-undang Jabatan Notaris dan Undang-undang Perseroan Terbatas. Kenyataannya terdapat Notaris yang diperkarakan karena telah membuat secara tidak benar Akta Pernyataan Keputusan Rapat (PKR) sebagaimana putusan Pengadilan Tinggi Banten nomor 9/Pid/2019/PT. Btn. Penelitian ini membahas kewenangan Notaris untuk membuat Akta Pernyataan Keputusan Rapat sesuai Undang-Undang Nomor 40 Tahun 2007 Tentang Perseroan Terbatas dan Undang-Undang Nomor 2 Tahun 2014 Tentang Perubahan Atas Undang-Undang Nomor 30 Tahun 2004 Tentang Jabatan Notaris dan pertanggungjawaban pidana Notaris terhadap Akta Pernyataan Keputusan Rapat yang dibuatnya tidak sesuai Undang-Undang Perseroan Terbatas dan Undang-Undang Jabatan Notaris (Studi Kasus: Putusan Pengadilan Tinggi Banten Nomor 9/Pid/2019/Pt. Btn). Dalam penelitian ini menggunakan metode penelitian hukum normatif. Hasil penelitian menunjukkan bahwa kewenangan Notaris untuk membuat Akta Pernyataan Keputusan Rapat Umum Pemegang Saham berdasarkan Pasal 15 ayat (1) Undang-Undang Jabatan Notaris dan Pasal 21 ayat (4) dan (5) Undang-Undang Perseroan Terbatas berdasarkan asli notulen atau risalah RUPS yang dibuat di bawah tangan sesuai anggaran dasar dan Undang-Undang Perseroan Terbatas dengan aturan dan tata cara pembuatan akta sesuai Undang-Undang Jabatan Notaris. Dalam perkara pidana tersebut Terdakwa selaku Notaris telah membuat secara tidak benar Akta Pernyataan Keputusan Rapat Pengalihan Saham dan Akta Jual Beli Saham yang mengakibatkan kerugian bagi pemegang saham yang sebenarnya, terbukti melanggar Pasal 264 ayat 1 ke-1 jo Pasal 55 ayat 1 ke-1 Kitab Undang-Undang Hukum Pidana dan harus mempertanggungjawabkannya dengan pidana penjara.
\end{abstract}

Kata Kunci: Kewenangan Notaris, Akta PKR, Pertanggungjawaban

\begin{abstract}
Amendments to the articles of association of a Limited Liability Company are determined by the General Meeting of Shareholders and published or stated in the notary deed (Article 19
\end{abstract}


paragraph (1) and Article 21 paragraph (4) of the Limited Liability Company Law). Notaries in making deeds related to amendments to the articles of association of a company should 
comply with the provisions of the Law on Notary Position and the Law on Limited Liability Companies. In fact, there is a Notary who is being sued because she made an incorrect Deed of Statement of Shareholders Resolutions as referred to Banten High Court decision number 9/Pid/2019/PT.Btn. This research discusses Notary's authority to make a Deed of Statement of Shareholders Resolutions in accordance with Law Number 40 of 2007 concerning Limited Liability Companies and Law Number 2 of 2014 concerning Amendments to Law Number 30 of 2004 concerning Notary Position and Notary's criminal responsibility towards the Deed of Statement of Shareholders Resolutions which made not in accordance with the Limited Liability Company Law and the Law on the Position of Notary (Case Study: Banten High Court Decision Number 9 / Pid / 2019 / Pt. Btn). In this study using normative legal research methods. The results showed that the Notary's authority to make a Deed of Decision of the General Meeting of Shareholders based on Article 15 paragraph (1) of the Law on Notary Position and Article 21 paragraph (4) and (5) of the Limited Liability Company Law based on the original minutes or minutes of the GMS made under hand in accordance with the articles of association and the Limited Liability Company Law with the rules and procedures for making deeds in accordance with the Law on Notary Position. In the criminal case, the Defendant as a Notary had incorrectly drawn up the Deed of Statement of Share Transfer Meeting Resolution and the Deed of Sale and Purchase of Shares which resulted in losses to the actual shareholders, proven to have violated Article 264 paragraph 1 to 1 in conjunction with Article 55 paragraph 1 to 1 of the Criminal Code and must be accounted for by imprisonment.

Keywords: Authority of Notary, Deed of Statement Meeting Resolutions (PKR), Responsibility

\section{PENDAHULUAN}

Suatu Perseroan Terbatas lahir sebagai badan hukum didasarkan pada keputusan pengesahan oleh Menteri sebagaimana ketentuan Pasal 7 ayat (2) Undang-Undang nomor 40 Tahun 2007 tentang Perseroan Terbatas. Keberadaannya sebagai badan hukum dibuktikan berdasarkan akta pendirian yang di dalamnya tercantum anggaran dasar Perseroan. ${ }^{1}$ Dalam Pasal 21 ayat (4) Undang-Undang Perseroan Terbatas menentukan perubahan anggaran dasar dimuat dan dinyatakan dalam akta Notaris, atas perubahan tersebut sebelumnya ditetapkan oleh keputusan Rapat Umum Pemegang Saham (RUPS) sebagaimana disyaratkan Pasal 19 ayat (1) Undang-Undang Perseroan Terbatas. Di dalam RUPS, pemegang saham mengambil keputusan, dan hal-hal yang dibicarakan serta diputuskan dicatat dalam risalah sebagaimana ditentukan Pasal 90 Undang-Undang Perseroan Terbatas yaitu:

(1) Setiap penyelenggaraan RUPS, risalah RUPS wajib dibuat dan ditandatangani oleh ketua rapat dan paling sedikit 1 (satu) orang pemegang saham yang ditunjuk dari dan oleh peserta RUPS.

(2) Tanda tangan sebagaimana dimaksud pada ayat (1) tidak disyaratkan apabila risalah RUPS tersebut dibuat dengan akta Notaris.

Walaupun risalah RUPS boleh dibuat dalam bentuk di bawah tangan, namun dalam hal RUPS memutuskan perubahan Anggaran Dasar, risalah bawah tangan tersebut harus dinyatakan dalam bentuk akta Notaris selambat-lambatnya 30 (tiga puluh) hari terhitung sejak tanggal keputusan RUPS sesuai ketentuan Pasal 21 ayat (5) Undang-Undang Perseroan Terbatas. ${ }^{2}$ Dalam praktik, umumnya penerima kuasa dari para pemegang saham, misalnya

${ }^{1}$ M. Yahya Harahap, Hukum Perseroan Terbatas, (Jakarta: Sinar Grafika, 2016), hlm. 37.

${ }^{2}$ Habib Adjie, Penafsiran Tematik Hukum Notaris Indonesia Berdasarkan Undang-Undang Nomor 2 Tahun 2014 Tentang Perubahan Atas Undang-Undang Tahun 2004 Tentang Jabatan Notaris, (Bandung: $\quad$ PT. $\quad$ Refika $\quad$ Aditama, 2015 ), hlm. 
Direksi akan menghadap kepada Notaris dan menyatakan hasil keputusan RUPS sebagaimana risalah RUPS bawah tangan ke dalam suatu akta Notaris yang demikian biasa disebut dengan "Akta Pernyataan Keputusan Rapat" dan merupakan akta partai. ${ }^{3}$

Akta Notaris adalah akta otentik yang dibuat oleh atau di hadapan Notaris menurut bentuk dan tata cara yang ditetapkan dalam Undang-Undang jabatan Notaris. ${ }^{4}$ Kewenangan Notaris untuk membuat akta otentik adalah sebagaimana ketentuan Pasal 15 ayat (1) UndangUndang nomor 2 tahun 2014 tentang perubahan atas Undang-Undang nomor 30 tahun 2004 tentang Jabatan Notaris yaitu "Notaris berwenang membuat akta otentik mengenai semua perbuatan, perjanjian, dan ketetapan yang diharuskan oleh peraturan perundang-undangan dan/atau yang dikehendaki oleh yang berkepentingan untuk dinyatakan dalam akta otentik, menjamin kepastian tanggal pembuatan akta, menyimpan akta, memberikan grosse, salinan dan kutipan akta, semuanya itu sepanjang pembuatan akta-akta itu tidak juga ditugaskan atau dikecualikan kepada pejabat lain atau orang lain yang ditetapkan oleh Undang-Undang".

Notaris bertanggung jawab atas akta yang dibuatnya sebagaimana Pasal 65 UndangUndang Jabatan Notaris. Semua perbuatan Notaris dalam menjalankan tugas kewajibannya harus dapat dipertanggungjawabkan secara hukum, termasuk segala konsekuensi untuk dikenakan sanksi hukum terhadap pelanggaran norma-norma hukum yang mendasarinya. ${ }^{5}$ Notaris adalah pejabat yang menuangkan keinginan para pihak, bersikap netral atau tidak berpihak kepada salah satu penghadap. Pada prinsipnya Notaris bertindak saksama, mandiri, jujur, berintegritas, beretika, bermoral dan tidak dapat diatur, ditekan dan tidak melakukan halhal negatif seperti turut serta melakukan atau menganjurkan atau membantu terjadinya tindak pidana. $^{6}$

Ketika para penghadap yang namanya tersebut dalam akta bersengketa ataupun ada pihak lain yang merasa dirugikan atas akta Notaris yang bersangkutan, sering dilakukan oleh mereka saling melaporkan atau mengadukan kepada penyidik (seperti kepolisian), dan dalam hal pelaporan atau pengaduan tersebut, Notaris akan dipanggil dan ditempatkan sebagai saksi untuk para pelapor atau yang mengadu tersebut. ${ }^{7}$ Tidak jarang berdasarkan hasil penyelidikan dan penyidikan tersebut, Notaris ditetapkan menjadi tersangka bersama-sama dengan para penghadap karena telah melakukan: ${ }^{8}$

1. Membuat surat palsu / yang dipalsukan dan menggunakan surat palsu / yang dipalsukan (Pasal 263 ayat (1), (2) KUHP);

2. Melakukan pemalsuan (Pasal 264 KUHP);

3. Menyuruh mencantumkan keterangan palsu dalam akta otentik (Pasal 266 KUHP);

4. Melakukan, menyuruh melakukan, yang turut serta melakukan (Pasal 55 jo Pasal 263 ayat (1) dan (2) atau 264 atau 266 KUHP).

Salah satu kasus Notaris yang diperkarakan oleh pihak yang merasa dirugikan atas akta-akta yang dibuatnya adalah sebagaimana putusan Pengadilan Tinggi Banten nomor: 9/PID/2019/PT. BTN, dimana Notaris RMR (Terdakwa) telah turut serta melakukan tindak pidana pemalsuan akta-akta autentik berupa Akta Pernyataan Keputusan Rapat Pengalihan Saham PT. PLCM Nomor 16 tanggal 26 Januari 2015 dan Akta Pernyataan Keputusan Rapat Pengalihan Saham PT. MAS nomor 18 tanggal 31 Januari 2015 dan akta jual beli saham

\footnotetext{
3 bid., hitm. 124.

${ }^{4}$ Wiratni Ahmadi, dkk., Teknik Pembuatan Akta Notaris, (Bandung: Logoz Publishing, 2016), hlm.7.

5/bid., hlm. 16.

${ }^{6}$ Sulhan, dkk., Profesi Notaris Dan Pe abat Pembuat Akta Tanah (Panduan Praktis Dan Mudah Taat Hukum), (Jakarta: Mitra Wacana Media, 2018), hlm. 22.

${ }^{7}$ Habib Adjie, Op.Cit., hlm. 166.

${ }^{8}$ Sjaifurrachman dan Habib Adjie, Aspek Pertanggung \}awaban Notaris dalam Pembuatan Akta, (Bandung: CV Mandar Maju, 2011), hlm. 167-168.
} 
PT. PLCM nomor 17 tanggal 26 Januari 2015 dan akta jual beli saham PT. MAS nomor 19 tanggal 30 Januari 2015 yang mengakibatkan kerugian bagi PT. CPA sebagai pemegang saham yang sebenarnya pada PT. PLCM dan PT. MAS.

Apabila ada akta Notaris yang dipermasalahkan oleh para pihak atau pihak lainnya seringpula Notaris ditarik sebagai pihak yang turut serta melakukan atau membantu melakukan suatu tindak pidana yaitu membuat atau memberikan keterangan palsu kedalam akta Notaris. Hal tersebut membuat kerancuan apakah mungkin Notaris secara sengaja culpa atau khilaf alpa bersama-sama dengan penghadap atau para penghadap membuat akta yang diniatkan sejak awal untuk melakukan suatu tindak pidana. ${ }^{9}$

Berdasarkan uraian latar belakang di atas, rumusan masalah yang dibahas mengenai: bagaimana kewenangan Notaris untuk membuat Akta Pernyataan Keputusan Rapat sesuai dengan Undang-Undang Nomor 40 Tahun 2007 Tentang Perseroan Terbatas dan UndangUndang Nomor 2 Tahun 2014 Tentang Perubahan Atas Undang-Undang Nomor 30 Tahun 2004 Tentang Jabatan Notaris dan bagaimana pertanggungjawaban pidana Notaris terhadap Akta Pernyataan Keputusan Rapat yang dibuatnya tidak sesuai dengan Undang-Undang Nomor 40 Tahun 2007 Tentang Perseroan Terbatas dan Undang-Undang Nomor 2 Tahun 2014 Tentang Perubahan Atas Undang-Undang Nomor 30 Tahun 2004 Tentang Jabatan Notaris (Studi Kasus: Putusan Pengadilan Tinggi Banten Nomor 9/Pid/2019/PT Btn).

\section{PENDEKATAN TEORI}

Untuk membahas dan menganalisis dalam penelitian ini, Penulis menggunakan teoriteori yang mendukung sebagai berikut:

1. Teori Kepastian Hukum

Kepastian memiliki arti ketentuan atau ketetapan. ${ }^{10}$ Sedangkan yang dimaksud dengan hukum adalah keseluruhan kumpulan peraturan-peraturan atau kaedah-kaedah dalam suatu kehidupan bersama: keseluruhan Peraturan tentang tingkah laku yang berlaku dalam suatu kehidupan bersama, yang dapat dipaksakan pelaksanaannya dengan suatu sanksi. ${ }^{11}$ Kepastian hukum itu sendiri dapat diartikan berlakunya hukum secara tegas ditengah-tengah masyarakat. Menurut Sudikno Mertokusumo kepastian hukum pada dasarnya pelaksanaan hukum sesuai dengan bunyinya sehingga masyarakat dapat memastikan bahwa hukum dilaksanakan. Kepastian hukum intinya adalah hukum ditaati dan dilaksanakan. ${ }^{12}$

Menurut Utrecht, kepastian hukum mengandung dua pengertian, yaitu pertama adanya aturan yang bersifat umum membuat individu mengetahui perbuatan apa yang boleh atau tidak boleh dilakukan, dan kedua, berupa keamanan hukum bagi individu dari kesewenangan pemerintah karena dengan adanya aturan yang bersifat umum itu individu dapat mengetahui apa saja yang boleh dibebankan atau dilakukan oleh Negara terhadap individu. Kepastian hukum ini berasal dari ajaran Yuridis-Dogmatik yang didasarkan pada aliran pemikiran Positivisme di dunia hukum yang cenderung melihat hukum sebagai sesuatu yang otonom yang mandiri, karena tujuan hukum tidak lain sekedar menjamin terwujudnya oleh hukum yang bersifat umum. Sifat umum dari aturan-aturan hukum membuktikan bahwa hukum tidak bertujuan untuk mewujudkan keadilan atau kemanfaatan, melainkan semata-mata untuk kepastian. ${ }^{13}$

\footnotetext{
${ }^{9}$ Ibid., hlm. 208.

${ }^{10}$ Margono, Asas Keadilan Kemanfaatan \& Kepastian Hukum Dalam Putusan Hakim, (Jakarta: Sinar Grafika, 2020), hlm. 115.

${ }^{11}$ Sudikno Mertokusumo, Mengenal Hukum Suatu Pengantar, (Yogyakarta: Liberty, 2003), hlm. 40.

${ }^{12}$ Margono, Op.Cit., hlm. 115.

${ }^{13}$ Riduan Syahrani, Rangkuman Intisari Ilmu Hukum, (Bandung: Citra Aditya Bakti, 1999), hlm. 
Menurut Gustav Radbruch, kepastian hukum menyangkut masalah "law being written down," bukan tentang keadilan dan kemanfaatan. Kepastian hukum itu tidak ada hubungannya dengan "die Sicherkeit durch das Recht," seperti memastikan, bahwa pencurian, pembunuhan, menurut hukum merupakan kejahatan. Kepastian hukum adalah "Sicherkeit des Rechts selbst" (kepastian tentang hukum itu sendiri). Ada empat hal yang berhubungan dengan makna kepastian hukum. Pertama, bahwa hukum itu positif, artinya bahwa ia adalah perundangundangan (gesetzliches Recht). Kedua, bahwa hukum ini didasarkan pada fakta (Tatsachen), bukan suatu rumusan tentang penilaian yang nanti akan dilakukan oleh hakim, seperti "kemauan baik," "kesopanan." Ketiga, bahwa fakta itu harus dirumuskan dengan cara yang jelas sehingga menghindari kekeliruan dalam pemaknaan, di samping juga mudah dijalankan. Keempat, hukum positif itu tidak boleh sering diubah-ubah. ${ }^{14}$

Menurut Van Apeldoorn, kepastian hukum mempunyai dua segi yaitu sebagai berikut:

a. Mengenai soal dapat ditentukannya (bepaalbaarheid) hukum dalam hal-hal yang konkret. Artinya pihak-pihak yang mencari keadilan ingin mengetahui apakah yang menjadi hukumnya dalam hal yang khusus sebelum ia memulai suatu perkara.

b. Kepastian hukum berarti keamanan hukum. Artinya perlindungan bagi para pihak terhadap kesewenangan hakim. ${ }^{15}$

2. Teori Kewenangan

Konsep teoritis tentang kewenangan H.D. Stoud, seperti dikutip Ridwan HB, menyajikan pengertian tentang kewenangan. Kewenangan adalah "Keseluruhan aturan-aturan yang berkenaan dengan perolehan dan penggunaan wewenang pemerintahan oleh subjek hukum publik di dalam hubungan hukum publik". ${ }^{16}$ Ada dua unsur yang terkandung dalam pengertian konsep kewenangan yang disajikan oleh H.D yaitu adanya aturan-aturan hukum dan sifat hubungan hukum. ${ }^{17}$ Sebelum kewenangan itu dilimpahkan kepada institusi yang melaksanakannya, maka terlebih dahulu harus ditentukan dalam peraturan perundangundangan, dalam bentuk Undang-Undang, peraturan pemerintah maupun aturan yang lebih rendah tingkatannya. Sifat hubungan hukum adalah sifat yang berkaitan dan mempunyai sangkut paut atau ikatan atau pertalian atau berkaitan dengan hukum. Hubungan hukumnya ada yang bersifat publik dan privat. ${ }^{18}$

F.A.M Strong dan J.G. Steenbeek, seperti dikutip oleh Ridwan HR mengemukakan dua cara organ pemerintah memperoleh kewenangan, yaitu atribusi dan delegasi. Atribusi berkenaan dengan penyerahan wewenang baru, sedangkan delegasi menyangkut pelimpahan wewenang yang telah ada (oleh organ yang telah memperoleh wewenang secara atributif kepada organ lain. Jadi secara logis selalu didahului oleh atribusi). ${ }^{19}$ Phimpus M Hadjon membagi cara memperoleh wewenang atas dua cara, yaitu atribusi dan delegasi dan kadangkadang juga mandat. ${ }^{20}$ Atribusi merupakan wewenang untuk membuat keputusan (besluit) yang langsung bersumber kepada Undang-Undang dalam arti materiil. Kewenangan yang didapat melalui atribusi oleh organ pemerintah adalah kewenangan asli, karena kewenangan itu diperoleh langsung dari peraturan perundang-undangan. Atribusi berarti timbulnya kewenangan baru yang sebelumnya kewenangan itu, tidak dimiliki oleh orang pemerintah yang bersangkutan. Sedangkan delegasi diartikan sebagai penyerahan wewenang untuk

\footnotetext{
${ }^{14}$ Satjipto Rahardjo, Hukum Dalam Jagat Ketertiban: Bacaan Mahasiswa Program Doktor /mu Hukum Universitas Diponegoro, (Jakarta: UKI Press, 2006), hlm. 136-137.

${ }^{15}$ Margono, Op.Cit., hlm. 117.

${ }^{16}$ Ridwan HR, Hukum Administrasi Negara, (Jakarta: Rajagrafindo Persada, 2008), hlm. 110.

${ }^{17}$ Salim HS dan Erlies Septiana Nurbani, Penerapan Teori Hukum Pada Penelitian Tesis dan Disertasi, (Jakarta: PT. RajaGrafindo Persada, 2018), hlm. 184.

$18 /$ bid.

${ }^{19}$ Ridwan HR, Op.Cit., hlm. 105.

${ }^{20}$ /bid., hlm. 195.
} 
membuat besluit oleh pejabat pemerintahan (pejabat tata usaha negara) kepada pihak lain tersebut. Dengan kata penyerahan, berarti adanya permindahan tanggung jawab dari yang memberi delegasi (delegans) kepada yang menerima delegasi (delegetaris).

3. Teori Pertanggungjawaban

Orang bertanggung jawab menurut Undang-Undang, bilamana dan segera ia menurut hukum harus bertanggungjawab atas kerugian yang ditimbulkannya. ${ }^{21}$ Menurut Abdulkadir Muhammad, terdapat beberapa teori tentang tanggung jawab dalam perbuatan melanggar hukum (tort liability) yaitu sebagai berikut: ${ }^{22}$

a. Tanggung jawab akibat perbuatan melanggar hukum yang dilakukan dengan sengaja (intentional tort liability)

b. Tanggung jawab akibat perbuatan melanggar hukum yang dilakukan dengan kelalaian (negligence tort liability)

c. Tanggung jawab mutlak akibat perbuatan melanggar hukum tanpa mempersoalkan kesalahan (strict liability)

Pada intentional tort liability, tergugat harus sudah melakukan perbuatan sedemikian rupa sehingga merugikan penggugat atau mengetahui bahwa apa yang dilakukan tergugat akan mengakibatkan kerugian, sedangkan hukum kelalaian (law of negligence) didasarkan pada konsep kesalahan (concept of fault) dalam mana lapangan moral dan hukum sudah bercampur baur (intermingled), dan pada perbuatan melanggar hukum yang menimbulkan tanggung jawab mutlak (strict liability) orang yang berbuat bertanggung jawab kendatipun perbuatannya dilakukan tidak sengaja atau tidak lalai. Artinya kendatipun bukan kesalahannya, dia tetap bertanggung jawab atas kerugian yang timbul akibat perbuatannya itu. ${ }^{23}$

Menurut Hans Kelsen, yang menguraikan teori tentang pertanggungjawaban dalam hukum yaitu suatu konsep terkait dengan konsep kewajiban hukum (responsibility) adalah konsep tanggungjawab hukum (liability). Seseorang yang bertanggungjawab secara hukum atas perbuatan tertentu bahwa dia dapat dikenakan suatu sanksi dalam kasus perbuatannya bertentangan/berlawanan hukum karena perbuatannya sendiri yang membuat orang tersebut bertanggungjawab. Normalnya, dalam suatu kasus sanksi dikenakan terhadap pelaku (deliquent) adalah karena perbuatannya sendiri yang membuat orang tersebut harus bertanggungjawab. ${ }^{24}$ Seorang individu secara hukum diwajibkan untuk berperilaku dengan cara tertentu, jika perilakunya yang sebaliknya merupakan syarat diberlakukannya tindakan paksa. Namun tindakan paksa ini tidak mesti ditujukan terhadap individu yang diwajibkan "pelaku pelanggaran"- namun dapat ditujukan kepada individu lain yang terkait dengan individu pertama dengan cara yang ditetapkan oleh tatanan hukum. Individu yang dikenakan sanksi dikatakan "bertanggung jawab" atau secara hukum bertanggung jawab atas pelanggaran. Hans Kelsen membagi pertanggungjawaban menjadi 4 (empat) macam yaitu ${ }^{25}$ :

a. Pertanggungjawaban individu berarti dia bertanggung jawab atas perlanggarannya sendiri dimana individu yang diwajibkan dan bertanggung jawab adalah identik.

b. Pertanggungjawaban kolektif berarti bahwa pertanggungjawaban atas suatu pelanggaran yang dilakukan oleh orang lain.

c. Pertanggungjawaban berdasarkan kesalahan yang berarti bahwa seorang individu bertanggung jawab atas pelanggaran yang dilakukannya karena sengaja dan diperkirakan

\footnotetext{
${ }^{21}$ Sjaifurrachman dan Habib Adjie, Op.Cit., hlm. 14.

${ }^{22}$ Abdulkadir Muhammad, Hukum Perusahaan /ndonesia, (Bandung: Citra Aditya Bakti, 2010), hlm. 535 .

$23 /$ bid.

${ }^{24}$ Jimly Asshiddiqie dan M. Ali Safa'at, Ter\}emahan Teori Hans Kelsen Tentang Hukum, Cet. ke-2, (Jakarta: Konstitusi Press, 2012), hlm. 56.

${ }^{25}$ Hans Kelsen, Pure Theory of Law, Ter\}emah, Raisul Muttaqien, Teori Hukum Murni: DasarDasar /mu Hukum Normatif, Cetakan XVII, (Bandung: Nusa Media, 2015), hlm. 137-138.
} 
dengan tujuan menimbukan kerugian. Pertanggungjawaban berdasarkan kesalahan biasanya mencakup persoalan kelalaian. Kelalaian terjadi ketika dibiarkannya tau tidak dicegahnya suatu kejadian yang tidak dikehendaki dari sudut pandang hukum merupakan hal yang terlarang, kendati kejadian itu tidak diperkirakan atau tidak disengajakan oleh individu itu, namun biasanya bisa diperkirakan dan tidak bisa disengajakan atau dicegah.

d. Pertanggungjawaban mutlak yang berarti bahwa seorang individu bertanggung jawab atas pelanggaran yang dilakukannya karena tidak sengaja dan tidak diperkirakan.

\section{METODE PENELITIAN}

Metode adalah suatu cara yang teratur dan terpikir dengan baik-baik untuk mencapai tujuan tertentu. ${ }^{26}$ Dalam penelitian ini penulis menggunakan metode penelitian hukum normatif. Soerjono Soekanto dan Sri Mamudji menyajikan pengertian penelitian hukum normatif adalah "Penelitian hukum yang dilakukan dengan cara meneliti bahan pustaka atau data sekunder belaka". ${ }^{27}$ Objek penelitiannya antara lain asas-asas dan prinsip-prinsip yang terkandung dalam peraturan Perundang-undangan, sistematika hukum, harmonisasi hukum, dan perbandingan hukum dari suatu peraturan Perundang-undangan. Pendekatan dilakukan dengan menelaah Undang-Undang dan regulasi yang bersaut pangkut dengan isu hukum yang sedang ditangani.

Sumber data yang digunakan adalah data sekunder dimana data utama berasal dari data kepustakaan / studi dokumen, di samping itu Penulis melakukan wawancara untuk mendukung pengumpulan data ke salah satu Kantor Notaris di Kota Depok. Studi kepustakaan dilakukan untuk memperoleh data yang berguna bagi penelitian yang didapat dari bahan hukum primer, bahan hukum sekunder dan bahan hukum tersier. ${ }^{28}$ Bahan hukum primer dalam penelitian ini adalah Undang-Undang Nomor 2 Tahun 2014 Tentang Perubahan Atas UndangUndang Nomor 30 Tahun 2004 Tentang Jabatan Notaris, Undang-Undang nomor 40 tahun 2007 tentang Perseroan Terbatas, Kitab Undang-Undang Hukum Pidana (KUH Pidana), Kitab Undang-Undang Hukum Perdata (KUH Perdata), Putusan Pengadilan Negeri Tangerang nomor 1857/Pid.B/2017/PN Tng tanggal 05 September 2018, Putusan Pengadilan Tinggi Banten nomor: 9/Pid/2019/PT Btn tanggal 05 Maret 2019. Untuk bahan hukum sekunder menggunakan buku-buku, jurnal-jurnal hukum, kamus-kamus hukum yang erat kaitannya dengan penelitian ini.

\section{HASIL PENELITIAN}

\section{A. Kasus Posisi}

Kasus ini sehubungan dengan membuat secara tidak benar (valschelijk opmaken) akta autentik berupa akta Pernyataan Keputusan Rapat Umum Pemegang Saham PT. PLCM nomor 16 tanggal 30 Januari 2015, Akta Pernyataan keputusan Rapat Umum Pemegang Saham PT. MAS nomor 18 tanggal 30 Januari 2015 dan membuat secara tidak benar surat berupa Akta Jual Beli Saham PT. PLCM nomor 17 tanggal 26 Januari 2015 dan Akta Jual Beli Saham PT. MAS nomor 19 tanggal 30 Januari 2015, perbuatan mana

\footnotetext{
${ }^{26}$ Salim HS dan Erlies Septiana Nurbani, Op.Cit., hlm. 8.

${ }^{27}$ Soerjono Soekanto dan Sri Mamudji, Penelitian Hukum Normatif Sebagai Tin\}auan Singkat, (Jakarta: Rajagrafindo, 2010), hlm. 13-14.

${ }^{28}$ Ishaq, Metode Penelitian Hukum Penulisan Skripsi, Tesis, Serta Disertasi, (Bandung: CV Alfabeta, 2017), hlm. 115.
} 
dilakukan oleh RMR selaku Notaris (Terdakwa) atas permintaan saksi YYK dan saksi AK sebagai berikut:

Permasalahan kasus ini berawal pada bulan Januari tahun 2015, dimana saksi YYK (dilakukan penuntutan terpisah) menyampaikan kepada Terdakwa memiliki 1.000 lembar saham pada PT. PLCM dan PT. MAS tetapi merasa di dzalimi karena kepemilikan sahamnya tersebut dihilangkan pihak lain. Terkait hal itu saksi YYK meminta kepada Terdakwa untuk melakukan proses pengembalian saham dengan cara membuatkan akta peralihan saham PT. PLCM dan PT. MAS kepada saksi YYK. Pada saat itu saksi YYK membawa fotocopy akta Notaris L nomor 2 tanggal 21 November 2009 tentang perubahan anggaran dasar PT. PLCM dengan susunan pemegang saham YYK: 1.000 lembar saham senilai Rp. 100.000.000 dan PT. CPA: 200 lembar saham senilai Rp. 20.000.000, serta YYK sebagai direktur utama. Adapun akta kepemilikan saham saksi YYK di PT MAS belum dibawa. Selanjutnya Terdakwa melakukan pengecekan ke Direktorat Jendral Administrasi Hukum Umum dan Kementerian Hukum dan Hak Asasi Manusia, akta nomor 2 tanggal 21 November 2009 tidak terdaftar. Pada saat itu pihak ditjen AHU telah menginformasikan akta-akta dan nomor surat keputusan Menteri Kehakiman PT. PLCM dari awal sampai akhir, dimana dalam akta-akta tersebut Terdakwa mengetahui tidak ada nama YYK sebagai pemegang saham ataupun pengurus PT. PLCM dan PT. MAS.

Pada tanggal 16 Januari 2015, Terdakwa bertemu dengan saksi YYK, saksi N, AJ saksi AK (dilakukan penuntutan terpisah) dirumah saksi AK, Terdakwa menjelaskan bahwa untuk dapat membuat akta perubahan dan dapat didaftarkan di Kehakiman harus ada syarat yang harus dipenuhi yaitu:

a. harus ada risalah rapat persetujuan pengalihan saham dari PT. CPA dan dari EG selaku pemegang saham PT. PLCM dan PT. MAS kepada YYK, AK, dan S

b. P selaku Direktur PT. CPA dapat menerima kuasa dari pemilik saham dan Direksi PT. CPA untuk mengalihkan saham milik PT. CPA di PT. PLCM dan PT. MAS kepada YYK, AK, dan S

Saat itu saksi YYK, N, AJ dan saksi AK menerangkan bahwa EG dan P akan tanda tangan risalah rapat dengan catatan $\mathrm{P}$ dibayar sebesar Rp. 5M untuk pelepasan PT. CPA dan PT. PLCM.

Pada tanggal 23 Januari 2015, Terdakwa bertemu kembali dengan saksi YYK, saksi YYK, saksi N, AS dirumah saksi AK. Pada saat itu saksi AK meminta Terdakwa untuk segera membuatkan akta peralihan saham PT. PLCM dan PT. MAS walaupun risalah rapat yang diisyaratkan belum ada. Selanjutnya pada tanggal 30 Januari 2015 bertempat di rumah Terdakwa di Kota Tangerang, Terdakwa membuat Akta Pernyataan Keputusan Rapat Pengalihan Saham PT. PLCM nomor 16 dan Akta Pernyataan Keputusan Rapat Pengalihan Saham PT. MAS nomor 18 meskipun telah mengetahui akta nomor 2 tanggal 21 Nopember 2009 yang menjadi dasar pengakuan saksi YYK atas kepemilikan saham di PT. PLCM tidak terdaftar di Ditjen AHU Kementerian Hukum dan HAM dan dalam akta pendirian serta perubahan PT. PLCM dan PT. MAS yang AHU tidak terdapat nama YYK, $\mathrm{AK}$, ataupun $\mathrm{S}$.

Terdakwa membuat dan menandatangani Akta Pernyataan Keputusan Rapat Pengalihan Saham PT. PLCM nomor 16 tanggal 26 Januari 2015 dan Akta Pernyataan Keputusan Rapat Pengalihan Saham PT. MAS Nomor 18 tanggal 26 Januari 2015 secara tidak benar dan tidak sesuai dengan fakta isi yang tercantum di dalam masing-masing akta tersebut sebab tidak benar pada hari, tanggal, bulan, dan tahun tersebut saksi YYK, KA dan S menghadap kepada Terdakwa di kantor Terdakwa di serang; YYK, AK, dan S bukan sebagai direktur utama, komisaris dan direktur operasional sebab PT. PLCM tidak pernah melakukan RUPS merubah susunan pengurus dan menggantikannya kepada YYK, AK dan S; PT. PLCM dan PT. MAS tidak pernah melakukan RUPSLB dan ketika menerbitkan akta 
tersebut Terdakwa tidak pernah melihat atau menerima notulen I berita acara RUPSLB tersebut; PT. CPA dan EG tidak pernah mengalihkan sahamnya pada PT. PLCM dan PT. MAS kepada saksi YYK, AK dan S serta tidak benar dan tidak sesuai dengan fakta bahwa akta tersebut dibuat dan diresmikan dengan $\mathrm{HH}$ dan EU sebagaimana disebutkan dalam akta. Untuk menguatkan kedua akta Terdakwa membuat Akta Jual Beli Saham PT. PLCM nomor 17 tanggal 26 Januari 2015 dan Akta Jual Beli Saham PT. MAS nomor 19 tanggal 30 Januari 2015 dengan mencantumkan isi yang tidak benar dan tidak sesuai dengan fakta yaitu $\mathrm{P}$ dan EG tidak pernah menghadap Terdakwa dan tidak benar ada surat kuasa Direksi kepada P sebagaimaan tersebut pada akta, PT. CPA dan EG tidak pernah menjual dan menyerahkan saham di PT. PLCM dan PT. MAS kepada YYK, AK, dan S, dan Akta HH dan S tidak pernah menyaksikan pembuatan akta sebagaimana disebutkan dalam akta.

Setelah menerbitkan akta-akta tersebut Terdakwa menyampaikan kepada YYK, AK, dan S, setelah dalam jangka waktu 1 (satu) bulan akta tersebut diterbitkan tetapi tidak ada risalah rapat, maka akta akan dibatalkan dan kembali ke posisi awal. Namun setelah 1 (satu) bulan Terdakwa tidak menerima risalah RUPS pengalihan saham PT. CPA di PT. PLCM dan PT. MAS, Terdakwa tidak membatalkan akta-akta tersebut, melainkan menginput perubahan akta ke sistem administrasi badan hukum (SABH) Dirjen Kemenkumham dan pada tanggal 27 Februari 2015 terbit surat keputusan Menkumham untuk PT. PLCM nomor: AHU-AH-01-03-0012527 dan nomor: AHU-AH-01-03-0012644 untuk PT. MAS.

Untuk mengurus legalitas perusahaan PT. PLCM dan PT. MAS, Terdakwa ada membuat akta perjanjian sewa Nomor 01 tanggal 2 Februari 2015 yang mencantumkan nama YYK sebagai direktur utama merujuk akta pernyataan keputusan rapat PT. PLCM yang diterbitkan tanpa adanya risalah I berita acara RUPS. Selanjutnya akta-akta tersebut digunakan YYK mengurus legalitas perusahaan PT. PLCM dan PT. MAS.

Terdakwa dalam membuat Akta Pernyataan Keputusan RUPS PT. PLCM nomor 16 tanggal 30 Januari 2015, Akta Jual Beli Saham PT. PLCM Nomor 17 Tanggal 26 Januari 2015, Akta Pernyataa Keputusan RUPS PT. MAS nomor 18 tanggal 30 Januari 2015 dan Akta Jual Beli Saham PT. MAS Nomor 19 tanggal 30 Januari 2015 telah menerima imbalan sebesar lebih kurang Rp. 825.000.000.

Selanjutnya pada tahun 2016 atas permintaan MH, Terdakwa menerbitkan akta Penegasan Kembali akta pernyataan keputusan rapat PT. PLCM nomor 06 tanggal 23 Februari 2016 dan akta Penegasan Kembali akta pernyataan keputusan rapat PT. MAS nomor 07 tanggal 23 Februari 2016 dengan merujuk pada Akta akta pernyataan keputusan rapat PT. PLCM Nomor 16 tanggal 26 Januari 2015 dan PKR PT. MAS nomor 18 tanggal 31 Januari 2015 yang Terdakwa buat secara tidak benar dan tidak didukung dengan dokumen-dokumen yang dipersyaratkan.

Perbuatan Terdakwa telah mengakibatkan PT. CPA mengalami kerugian materiil yaitu hilangnya saham PT. CPA pada PT. PCLM dan PT. MAS dan kehilangan haknya untuk melakukan perbuatan hukum seagai pemegang saham mayoritas PT. PLCM dan PT. MAS yaitu tidak dapat menginput perubahan hasil RUPS PT. PLCM dan PT. MAS dalam Akta PT. PLCM nomor 93 tanggal 21 April 2015 dan Akta PT. MAS nomor 93 tanggal 21 April 2015. Kedua akta tersebut tidak dapat dilaporkan ke Ditjen AHU karena ditolak pada saat menginput ke dalam database dengan alasan ada perubahan pemegang saham dan pengurus dalam akta yang dibuat oleh Terdakwa yang tidak diketahui oleh Pihak PT. CPA selaku pemegang saham. Terdakwa diajukan ke persidangan oleh Penuntut umum dengan dakwaan sebagai berikut:

\section{KESATU:}


Bahwa Terdakwa RMR, S.H., M.Kn., baik sendiri-sendiri maupun secara bersama-sama dengan YYK dan AK (dalam berkas terpisah) pada sekitar bulan Januari 2015, atau setidaktidaknya dalam tahun 2015 bertempat di rumah Terdakwa di Kota Tangerang atau setidaktidaknya pada tempat lain yang masih termasuk dalam wilayah hukum Pengadilan Negeri Tangerang, telah melakukan, menyuruh melakukan, turut serta melakukan membuat secara tidak benar atau memalsu surat yang dapat menimbulkan sesuatu hak, perikatan atau pembebasan hutang, atau yang diperuntukan sebagai bukti dari sesuatu hal dengan maksud untuk memakai atau menyuruh orang lain pakai surat tersebut seolah-olah isinya benar dan tidak dipalsu dan pemakaian tersebut dapat menimbulkan kerugian, perbuatan mana dilakukan terhadap akta-akta otentik, perbuatan mana dilakukan Terdakwa bersama dengan YYK dan AK.

Perbuatan Terdakwa sebagaimana diatur dan diancam pidana dalam Pasal 264 ayat (1) ke1 jo Pasal 55 ayat (1) ke-1 KUHP, atau

KEDUA:

Bahwa ia Terdakwa RMR, S.H., M.Kn., baik sendiri-sendiri maupun secara bersama-sama dengan YYK dan AK (dalam berkas terpisah) pada sekitar bulan Januari 2015 atau setidaktidaknya dalam tahun 2015 bertempat di rumah Terdakwa di Kota Tangerang atau setidaktidaknya pada tempat lain yang masih termasuk dalam wilayah hukum Pengadilan Negeri Tangerang, telah melakukan, menyuruh melakukan, turut serta melakukan, sengaja memakai surat yang telah dipalsukan, yang isinya tidak benar atau yang dipalsu seolaholah benar dan tidak dipalsu, dan pemakaian tersebut dapat menimbulkan kerugian. Perbuatan mana dilakukan Terdakwa bersama dengan YYK dan AK.

Perbuatan Terdakwa sebagaimana diatur dan diancam pidana dalam Pasal 264 ayat (2) Jo Pasal 55 ayat (1) ke-1e KUHP.

Menimbang bahwa untuk menentukan apakah Terdakwa telah bersalah berdasarkan bukti-bukti yang diajukan di persidangan telah melakukan tindak pidana sebagaimana didakwakan oleh Penuntut Umum harus terbukti dan memenuhi unsur-unsur dari tindak pidana yang didakwakan.

Menimbang bahwa Terdakwa dihadapkan kemuka persidangan dengan dakwaan alternative yaitu Kesatu Pasal 264 ayat (1) jo Pasal 55 ayat (1) ke-1e Kitab Undang-Undang Hukum Pidana atau kedua Pasal 264 ayat (2) Jo Pasal 55 ayat (1) ke-1e Kitab UndangUndang Hukum Pidana sehingga Majelis Hakim akan langsung memperhatikan fakta-fakta hukum yang terbukti di persidangan yaitu dakwaan kesatu sebagaimana diatur dalam Pasal 264 ayat (1) jo Pasal 55 ayat (1) ke-1e Kitab Undang-Undang Hukum Pidana yang unsurunsurnya adalah sebagai berikut:

1. Barang siapa;

2. Membuat secara tidak benar atau memalsu surat;

3. Yang dapat menimbulkan sesuatu hak, perikatan atau pembebasan hutang atau yang di peruntukkan sebagai bukti dari sesuatu hal;

4. Dengan maksud untuk memakai atau menyuruh orang lain pakai surat tersebut seolah-olah isinya benar dan tidak dipalsu;

5. Pemakaian tersebut dapat menimbulkan kerugian;

6. Terhadap akta autentik;

7. Sebagai yang turut serta melakukan;

\section{B. Putusan Hakim}

Putusan Pengadilan Tinggi Banten Nomor: 9IPIDI2019IPT BTN:

Mengingat Pasal 264 ayat 1 ke 1 jo Pasal 55 ayat 1 ke 1 KUHP, Undang-Undang nomor 8

Tahun 1981 Tentang KUHAP dan ketentuan-ketentuan hukum lainnya:

MENGADILI: 
- Menerima permohonan banding dari Penuntut umum

- Memperbaiki Putusan Pengadilan Negeri Tangerang Nomor: 1857IPid.BI2017IPN. Tng pada tanggal 5 September 2018 tentang pidana yang dijatuhkan kepada Terdakwa sehingga amar selengkapnya sebagai berikut:

1. Menyatakan Terdakwa RMR, SH, M.Kn., tersebut, terbukti secara sah dan meyakinkan bersalah melakukan tindak pidana "Turut Serta Melakukan Pemalsuan Akta-Akta Autentik";

2. Menjatuhkan pidana kepada Terdakwa oleh karena itu dengan pidana penjara selama 10 (sepuluh) bulan;

3. Menetapkan lamanya Terdakwa dalam tahanan dikurangkan seluruhnya dari pidana yang dijatuhkan.;

4. Memerintahkan agar Terdakwa ditahan;

C. Kewenangan Notaris Untuk Membuat Akta Pernyataan Keputusan Rapat Sesuai Dengan Undang-Undang Nomor 40 Tahun 2007 Tentang Perseroan Terbatas Dan Undang-Undang Nomor 2 Tahun 2014 Tentang Perubahan Atas Undang-Undang Nomor 30 Tahun 2004 Tentang Jabatan Notaris

Sehubungan dengan kewenangan Notaris Untuk Membuat Akta Pernyataan Keputusan Rapat Sesuai Dengan Undang-Undang Nomor 40 Tahun 2007 Tentang Perseroan Terbatas Dan Undang-Undang Nomor 2 Tahun 2014 Tentang Perubahan Atas Undang-Undang Nomor 30 Tahun 2004 Tentang Jabatan Notaris, Notaris merupakan salah satu pihak yang mempunyai peran penting dalam kegiatan Perseroan Terbatas terutama berkaitan dengan kewenangan membuat Akta otentik.

Dalam Pasal 1 angka 1 Undang-Undang Jabatan Notaris, Notaris merupakan Pejabat umum yang berwenang untuk membuat akta autentik dan memiliki kewenangan lainnya dan Pasal 15 ayat (1) Undang-Undang Jabatan Notaris menyatakan bahwa Notaris berwenang untuk membuat akta otentik yang menyangkut semua perbuatan, perjanjian, dan ketetapan yang diharuskan oleh peraturan perundang-undangan dan I atau yang dikehendaki oleh yang berkepentingan untuk dinyatakan dalam akta otentik, dan menjamin kepastian tanggal pembuatan akta, menyimpan Akta, memberikan grosse, salinan dan kutipan Akta, semuanya itu sepanjang pembuatan Akta itu tidak juga ditugaskan atau di kecualikan kepada pejabat lain atau orang lain yang ditetapkan oleh Undang-Undang. Sesuai Pasal 1 angka 1 dan Pasal 15 ayat (1) Undang-Undang Jabatan Notaris tersebut kewenangan Notaris berdasarkan Undang-Undang Jabatan Notaris, menurut UndangUndang lain yang menyebutkan atau menentukan suatu perbuatan atau tindakan hukum wajib dibuat dalam bentuk akta Notaris, menurut Peraturan Perundang-undangan (jenis Peraturan perundang-undangan yang lain) yang menyebutkan atau menentukan suatu perbuatan atau tindakan hukum wajib dibuat dalam bentuk akta Notaris.

Kewenangan merupakan suatu tindakan hukum yang diatur dan diberikan kepada suatu jabatan berdasarkan peraturan perundang-undangan yang berlaku yang mengatur jabatan yang bersangkutan. Setiap wewenang ada batasannya sebagaimana peraturan perundang-undangan yang mengaturnya. ${ }^{29}$ Kewenangan Notaris untuk membuat akta otentik merupakan kewenangan atribusi, dimana kewenangan tersebut diberikan oleh undang-undang dalam hal ini adalah Undang-Undang Jabatan Notaris. Sehingga Notaris memiliki legalitas untuk melakukan perbuatan hukum membuat akta otentik sebagaimana disebutkan Pasal 1 angka 1 Undang-Undang Jabatan Notaris dan ditegaskan Pasal 15 ayat (1) Undang-Undang Jabatan Notaris.

${ }^{29}$ Sulhan, dkk., Op.Cit., hlm. 6 
Kewenangan Notaris dalam Pasal 15 ayat (1) Undang-Undang Jabatan Notaris sejalan dengan ketentuan Pasal 21 ayat (4) Undang-Undang Perseroan Terbatas bahwa perubahan anggaran dasar dimuat atau dinyatakan dalam akta Notaris dan pada ayat (5) bahwa perubahan anggaran dasar yang tidak dimuat dalam akta berita acara rapat yang dibuat Notaris harus dinyatakan dalam akta Notaris paling lambat 30 (tiga puluh) hari terhitung sejak tanggal keputusan RUPS. Perubahan anggaran dasar Perseroan Terbatas ditetapkan oleh keputusan RUPS sebagaimana diatur Pasal 19 ayat (1) Undang-Undang Perseroan Terbatas. Keputusan dan hal-hal yang dibicarakan serta diputuskan dalam RUPS dicatat dalam sebuah risalah yantg mana berdasarkan Pasal 90 ayat (1) Undang-Undang Perseroan Terbatas tidak harus dibuat dengan akta Notaris. Dengan kata lain risalah RUPS dapat dibuat dengan bentuk akta dibawah tangan dengan ketentuan risalah RUPS tersebut wajib ditandatangani oleh ketua rapat dan paling sedikit satu orang pemegang saham yang ditunjuk dari dan oleh peserta RUPS. ${ }^{30}$ Jika risalah RUPS dibuat dalam bentuk di bawah tangan dan keputusan tersebut berkaitan dengan perubahan anggaran dasar, hasil keputusan rapat tersebut harus dinyatakan dalam akta Notaris dengan memperhatikan jangka waktu untuk menyatakannya sebagaimana ketentuan Pasal 21 ayat (4) Undang-Undang Perseroan Terbatas jo ayat (5) Undang-Undang Perseroan Terbatas. Penjelasan Pasal 21 ayat (5) bahwa "harus dinyatakan dengan akta Notaris" adalah harus dalam bentuk Akta Pernyataan Keputusan Rapat atau akta perubahan anggaran dasar. Dalam hal berita acara RUPS adalah mengenai perubahan anggota direksi atau dewan komisaris Perseroan selain jangka waktu untuk menyatakan, maka bentuk Akta Pernyataan Keputusan Rapatnya adalah akta pihak. ${ }^{31}$

Berbeda dengan risalah RUPS yang dibuat dalam bentuk Akta Notaris (biasa disebut dengan Akta Berita Acara Rapat) yang merupakaan akta relaas. Notaris hadir pada saat RUPS dan kemudian menulis apa yang disaksikannya pada saat rapat di dalam akta tersebut. Sesuai dengan ketentuan Pasal 90 ayat (2) Undang-Undang Perseroan Terbatas juncto Pasal 46 ayat (1), pada Akta Berita Acara RUPS yang dibuat oleh Notaris, tanda tangan penghadap atau peserta rapat bukan merupakan syarat mutlak, asalkan alasan tidak ditandatanganinya akta itu dinyatakan di dalam akta tersebut. Notaris hadir menyaksikan pengambilan keputusan yang dilakukan oleh pemegang saham dan kemudian menuangkannya di dalam Akta Berita Acara RUPS. Notarislah yang harus menjamin bahwa hal-hal yang tertuang di dalam akta itu sesuai dengan kenyataan yang disaksikan. Bahkan jika penghadap dalam RUPS tersebut menolak untuk menandatangani ataupun sudah pergi pada saat penutupan akta sehingga tidak bisa menandatangani minuta akta, Akta Berita Acara RUPS tersebut tetap diakui sebagai akta otentik. ${ }^{32}$

Menurut Herlien Budiono, akta pihak merupakan akta yang berisikan mengenai apa yang terjadi berdasarkan keterangan yang diberikan oleh penghadap kepada Notaris, mereka menerangkan dan menceritakan kepada Notaris dan untuk keperluan tersebut sengaja datang kepada Notaris agar keterangan atau perbuatan tersebut dinyatakan oleh Notaris di dalam suatu akta Notaris dan yang (para) penghadap menandatangani akta itu. Berdasarkan ketentuan Pasal 15 ayat (1) Undang-Undang Jabatan Notaris bahwa "Notaris berwenang membuat akta autentik" dalam pengertian teknis "membuat" atau "verli\}den" adalah melakukan sejumlah pekerjaan yang diperlukan untuk terjadinya akta (Notaris). Pada akta pihak "membuat" akta terdiri atas penyusunan yaitu pembacaan akta oleh Notaris serta penandatangan akta oleh para penghadap, para saksi, dan Notaris. ${ }^{33}$

\footnotetext{
${ }^{30} /$ bid.

${ }^{31}$ Herlien Budiono, Dasar Teknik Pembuatan Akta Notaris, (Bandung: PT. Citra Aditya Bakti,

${ }^{32}$ Habib Adjie, Op.Cit., hlm. 124.

${ }^{33}$ Herlien Budiono, Op.Cit., hlm. 7.
} 2017), hlm. 162. 
Menurut Tan Thong Kie, pembuatan akta merupakan proses verbal pekerjaanpekerjaan oleh pegawai umum dalam pembuatan akta-akta yang meliputi:

1. Dilihatnya kenyataan oleh Notaris tentang suatu tindakan atau kejadian;

2. Diceritakannya secara tertulis oleh Notaris;

3. Pembacaan oleh Notaris dan penandatanganan oleh yang berkepentingan, termasuk mengkonstatir penolakannya dan lagi kepergian seorang sebelum penandatangan akta. $^{34}$

Sepanjang mengenai akta pihak yang dijamin keabsahannya sebagai akta otentik harus memuat syarat-syarat sebagai berikut:

1. Tanggal dari akta itu

2. Tanda tangan yang ada dalam akta itu

3. Identitas dari orang yang hadir

4. Bahwa apa yang tercantum dalam akta itu adalah sesuai dengan apa yang diterangkan oleh para penghadap kepada Notaris untuk dicantumkan dalam bentuk akta itu, sedangkan kebenaran dari keterangan-keterangan itu sendiri hanya pasti antara pihak-pihak yang bersangkutan sendiri. ${ }^{35}$

Notaris dalam membuat akta pihak harus memperhatikan ketentuan syarat sahnya akta Notaris. Notaris mempunyai kewajiban sebagaimana Pasal 16 Undang-Undang Jabatan Notaris, selain itu syarat sah sebuah Akta Notaris berdasarkan bentuknya ditentukan Pasal 38 Undang-Undang Jabatan Notaris dari awal akta atau kepala akta, badan akta, dan akhir atau penutup akta, dan masing-masing dari bagian akta dijelaskan secara rinci dalam ayat (2), ayat (3) dan ayat (4). Syarat sebuah akta Notaris tidak hanya terhadap bentuk akta, tetapi juga kecakapan pihak yang menghadap dan saksi sebagaimana Pasal 39 dan Pasal 40 Undang-Undang Jabatan Notaris.

Menurut Purwanto, Akta Pernyataan Keputusan Rapat Perseroan Terbatas merupakan Akta yang dibuat oleh Notaris atas permintaan pihak yang berhaklberwenang yang diberikan oleh rapat untuk menghadap Notaris, yang isinya merupakan pernyataan berdasarkan apa yang dimuat di dalam Notulen 1 risalah RUPS Perseroan Terbatas yang dibuat dibawah tangan yang telah ditandatangani Pemegang saham sesuai dengan ketentuan Anggaran Dasar Perseroan Terbatas dan kelengkapan dokumen pendukung lainnya. ${ }^{36}$ Notaris berwenang untuk membuat Akta Pernyataaan Keputusan Rapat sehubungan dengan perubahan Anggaran Dasar Perseroan Terbatas atas permintaan pihak yang memiliki legal standing yang diberikan oleh rapat untuk menghadap Notaris untuk menyatakan hasil rapat tersebut dalam akta pernyataan keputusan rapat berdasarkan notulenlrisalah RUPS dengan dilengkapi dokumen-dokumen pendukung sebagai syarat formal pembuatan akta tersebut. Selanjutnya Notaris mengkaji apakah notulenlrisalah RUPS yang dibuat dibawah tangan tersebut sesuai anggaran dasar dan Undang-Undang Perseroan terbatas. Apabila sesuai maka Notaris mempunyai kewenangan untuk membuat akta akta pernyataan keputusan rapat dalam bentuk minuta selanjutnya membacakan di hadapan penghadap dengan dihadiri oleh 2 (dua) orang saksi dan ditandatangani pada saat itu juga oleh penghadap, saksi-saksi, dan Notaris. ${ }^{37}$

Dalam menjalankan wewenangnya, Notaris sebagai pejabat umum memiliki ciri utama yaitu pada kedudukannya yang tidak memihak dan mandiri (independent), Notaris

${ }^{34}$ Tan Thong Kie, Studi Notariat \& Serba-Serbi Praktek Notaris, (Jakarta: PT. Ichtiar Baru Van Hoeve, 2011), hlm. 491-492.

${ }^{35}$ R. Soegondo Notodisoerjo, Hukum Notariat di Indonesia Suatu Pen\}elasan, (Jakarta: Raja Grafindo Persada, 1993), Op.Cit., hlm. 53.

${ }^{36}$ Purwanto, wawancara pribadi, Notaris, Depok, 27 November 2020.

${ }^{37}$ Ibid. 
netral tidak memihak kepada salah satu dari mereka yang berkepentingan. ${ }^{38}$ Apabila terdapat pihak yang menghadap kepada Notaris dan meminta untuk dibuatkan Akta Pernyataan Keputusan Rapat namun tidak memiliki kewenangan bertindak atau tidak menyerahkan asli notulen RUPS dan dokumen lain sebagai syarat formal pembuatan akta sesuai Anggaran Dasar, Undang-Undang Perseroan Terbatas, dan Undang-Undang Jabatan Notaris maka Notaris wajib untuk menolaknya. ${ }^{39}$ Kewajiban untuk menolak tersebut dengan alasan sebagaimana Pasal 16 ayat (1) huruf e Undang-Undang Jabatan Notaris. Notaris tidak mempunyai kewenangan untuk membuat Akta Pernyataan keputusan Rapat hanya berdasarkan permintaan keterangan lisan dari pihak yang tidak memiliki kewenangan bertindak atau hanya berdasarkan kepercayaan misalnya pihak menjanjikan akan memberikan notulen RUPS menyusul atau setelah akta selesai. Tanpa adanya notulen RUPS dibawah tangan sesuai Anggaran Dasar Perseroan, Undang-Undang Perseroan Terbatas dan dokumen pendukung, Notaris tidak mempunyai kewenangan untuk membuat akta Akta Pernyataan yang diminta karena tidak ada akta yang dibuat dengan mendahului syarat formal dari akta tersebut. ${ }^{40}$

Akta yang dibuat oleh Notaris mempunyai peranan penting dalam menciptakan kepastian dan perlindungan hukum terkait dengan status, hak dan kewajiban seseorang di dalam setiap hubungan hukum, sebab akta Notaris bersifat akta otentik dan merupakan alat bukti terkuat dan terpenuh dalam setiap perkara yang terkait dengan akta Notaris tersebut. Sebagai alat bukti tertulis yang terkuat dan terpenuh apa yang dinyatakan dalam akta Notaris harus diterima, kecuali pihak yang berkepentingan dapat membuktikan hal yang sebaliknya di hadapan persidangan Pengadilan. ${ }^{41}$ Sehingga apabila Notaris dalam menjalankan kewenangannya membuat akta tidak sesuai ketentuan atau melanggar tata cara atau prosedur pembuatan akta dan aturan hukum yang berkaitan dengan tindakan hukum dalam akta tersebut sehingga menimbulkan kerugian bagi (para) penghadap atau pihak lain yang terkait dengan akta dimaksud maka Notaris yang bersangkutan dapat dimintai pertanggungjawabkan secara hukum termasuk secara hukum pidana.

Dalam hal Notaris dalam menjalankan tugas dan jabatannya terbukti melakukan pelanggaran maka ia dapat dikenai sanksi, salah satunya adalah sanksi pidana. Namun demikian dalam Undang-Undang Jabatan Notaris tidak mengatur sanksi pidana. Maka apabila terjadi pelanggaran pidana terhadap Notaris dapat dikenakan sanksi pidana yang terdapat dalam Kitab Undang-Undang Hukum Pidana, dengan catatan bahwa pemidanaan terhadap Notaris tersebut dapat dilakukan dengan batasan yaitu: ${ }^{42}$

1. Ada tindakan hukum dari Notaris terhadap aspek lahiriah, formal dan materil akta yang sengaja, penuh kesadaran dan keinsyafan, serta direncanakan bahwa akta yang akan dibuat dihadapan Notaris oleh Notaris bersama-sama (sepakat) para penghadap dijadikan dasar untuk melakukan suatu tindak pidana.

2. Ada tindakan hukum Notaris dalam membuat akta dihadapan atau oleh Notaris yang apabila diukur berdasarkan Undang-Undang Jabatan Notaris tidak sesuai dengan Undang-Undang Jabatan Notaris.

3. Tindakan Notaris tersebut juga tidak sesuai menurut instansi yang berwenang untuk menilai tindakan suatu Notaris, dalam hal ini Majelis Pengawas Notaris.

\footnotetext{
${ }^{38}$ Sjaifurrachman dan Habib Adjie, Op.Cit., hlm. 65.

${ }^{39}$ Purwanto, wawancara pribadi, Notaris, Depok, 27 November 2020.

${ }^{40} /$ bid.

${ }^{41}$ Sjaifurrachman dan Habib Adjie, Op.Cit., hlm. 7-8.

42/bid. hlm. 208-209.
} 
D. Pertanggungjawaban pidana Notaris terhadap Akta Pernyataan Keputusan Rapat yang dibuatnya tidak sesuai dengan Undang-Undang Nomor 40 Tahun 2007 Tentang Perseroan Terbatas dan Undang-Undang Nomor 2 Tahun 2014 Tentang Perubahan Atas Undang-Undang Nomor 30 Tahun 2004 Tentang Jabatan Notaris (Studi Kasus: Putusan Pengadilan Tinggi Banten Nomor 9/Pid/2019/Pt. Btn)

Seorang Notaris dapat bertanggung jawab apabila dapat dibuktikan bahwa Notaris tersebut bersalah. Terkait dengan kesalahan Notaris yang digunakan adalah beroepsfout yang merupakan istilah khusus yang ditujukan terhadap kesalahan. Kesalahan tersebut dilakukan oleh para profesional dengan jabatan khusus yaitu dokter, Advokat, dan Notaris. Kesalahan-kesalahan tersebut dilakukan dalam menjalankan suatu jabatan. Untuk mengkaji pengertian kesalahan pada beroepsfout dapat mengacu pada definisi kesalahan pada umumnya, khususnya dalam hukum pidana. Disamping pengertian kesalahan objektif, juga terdapat persyaratan secara khusus untuk dapat mendalilkan bahwa Notaris telah bersalah dalam menjalankan jabatannya. ${ }^{43}$

Sehubungan dengan perkara pidana dalam putusan Pengadilan Tinggi Banten nomor: 91PIDI20191PT BTN, Terdakwa selaku Notaris dihadapkan ke muka persidangan dengan dakwaan alternatif yaitu kesatu Pasal 264 ayat (1) jo Pasal 55 ayat (1) ke-1e Kitab Undang-Undang Hukum Pidana atau kedua Pasal 264 ayat (2) Jo Pasal 55 ayat (1) ke-1e Kitab Undang-Undang Hukum Pidana. Berdasarkan fakta-fakta hukum di persidangan, Majelis Hakim berkeyakinan bahwa semua unsur dalam dakwaan kesatu telah terpenuhi. Terdakwa RMR terbukti telah turut serta melakukan pemalsuan akta autentik melanggar Pasal 264 ayat (1) jo Pasal 55 ayat (1) ke-1 KUHP.

Terdakwa atas permintaan saksi YYK dan saksi saksi AK telah membuat secara tidak benar (valschelijk opmaken) Akta Pernyataan Keputusan Rapat Umum Pemegang Saham PT. PLCM nomor 16 tanggal 30 Januari 2015, Akta Pernyataan Keputusan Rapat Umum Pemegang Saham PT. MAS nomor 18 tanggal 30 Januari 2015 dan membuat secara tidak benar surat berupa Akta Jual Beli Saham PT. MAS nomor 19 tanggal 30 Januari 2015 dan Akta Jual Beli Saham PT. PLCM nomor 17 tanggal 26 Januari 2015. Dimana pada tanggal 30 Januari 2015 bertempat dirumah Terdakwa di Kota Tangerang, Terdakwa membuat minuta Akta Pernyataan Keputusan Rapat Pengalihan Saham PT. PLCM nomor 16 dan Akta Pernyataan Keputusan Rapat Pengalihan Saham PT. MAS nomor 18, meskipun telah mengetahui akta nomor 2 tanggal 21 Nopember 2009 yang menjadi dasar pengakuan saksi YYK atas kepemilikan saham di PT. PLCM dan PT. MAS tidak terdaftar di Ditjen AHU Kementerian Hukum dan HAM dan pada akta pendirian serta perubahan PT. PLCM dan PT. MAS yang terdaftar pada Ditjen AHU tidak ada nama YYK sebagai pemegang saham ataupun pengurus. Selanjutnya minuta akta ditandatangani oleh saksi YYK dan saksi AK di rumah saksi AK, bukan di kantor Terdakwa, dan saksi S baru menandatangani minuta akta pada bulan Maret 2015 di sebuah hotel di Jakarta Pusat. Terdakwa membuat dan menandatangani akta Pernyataan Keputusan Rapat pengalihan Saham PT. PLCM Nomor 16 Tanggal 26 Januari 2015 dan Akta Pernyataan Pengalihan Saham PT. MAS Nomor 18 Tanggal 26 Januari 2015 tanpa dilengkapi persyaratan yaitu risalah rapat pemegang saham PT. PLCM dan PT. MAS tentang jual beli saham kepada saksi YYK dan surat kuasa Direksi PT. CPA kepada P. Terdakwa memasukkan keterangan yang tidak benar pada isi kedua akta tersebut.

Setelah menerbitkan akta-akta tersebut, Terdakwa meminta kepada saksi YYK, AK, dan S agar dalam jangka waktu 1 (satu) bulan setelah akta tersebut terbit tetapi tidak ada risalah rapat dan surat kuasa Direksi kepda $\mathrm{P}$, maka akta akan dibatalkan dan kembali ke posisi awal. Namun setelah 1 (satu) bulan saksi YYK dan saksi AK tidak menyerahkan

\footnotetext{
${ }^{43}$ Sjaifurrachman dan Habib Adjie, Op. Cit., hlm. 173.
} 
risalah RUPS pengalihan saham PT. CPA di PT, PLCM dan PT. MAS dan surat kuasa Direksi kepada P, Terdakwa tidak membatalkan akta-akta tersebut, melainkan menginput perubahan akta ke sistem administrasi badan hukum (SABH) Dirjen Kemenkumham hingga pada tanggal 27 Februari 2015 terbit surat keputusan Menkumham Nomor: AHUAH-01-03-0012527 untuk PT. PLCM dan Nomor: AHU-AH-01-03-0012644 PT. MAS. Selanjutnya tahun 2016 atas permintaan MH, Terdakwa membuat Akta Penegasan Kembali Akta Pernyataan Keputusan Rapat PT. PLCM nomor 06 tanggal 23 Februari 2016 dan Akta Penegasan Kembali Akta Pernyataan Keputusan Rapat PT. MAS nomor 07 tanggal 23 Februari 2016. Terdakwa mencantumkan nama saksi YYK, saksi AK, dan saksi S sebagai pemilik saham dan pengurus Perseroan PT. PLCM dan PT. MAS sebelumnya beralih kepada PT. BR dengan merujuk pada Akta Pernyataan Keputusan Rapat Pengalihan Saham PT. PLCM Nomor 16 tanggal 30 Januari 2015 dan Akta Pernyataan Keputusan Rapat Pengalihan Saham PT. MAS nomor 18 tanggal 26 Januari 2015 yang dibuat tanpa dilengkapi dengan dokumen yang dipersyaratkan untuk penerbitan akta tersebut.

Akta-akta yang dibuat secara tidak benar tersebut telah menimbulkan hak bagi saksi YYK, saksi AK dan saksi S yaitu hak atas saham-saham PT. PLCM dan PT. MAS, hak sebagai 'pengurus' PT. PLCM dan PT. MAS, hak untuk mengalihkan saham PT. PLCM dan PT. MAS kepada pihak lain sebagaimana Akta Penegasan kembali Pernyataan Keputusan Rapat PT. PLCM nomor 06 tanggal 23 Februari 2016 dan Akta Penegasan Kembali Pernyataan Keputusan Rapat PT. MAS nomor 07 tanggal 23 Februari 2016, serta hak bagi YYK untuk bertindak mewakili PT. PLCM dan PT. MAS mengurus legalitas perusahaan. Akta-akta tersebut juga telah dijadikan bukti untuk mengurus legalitas perusahaan, telah Terdakwa gunakan untuk menginput perubahan data Perseroan PT. PLCM dan PT. MAS pada ditjen AHU kementerian Hukum dan HAM sehingga terbit surat keputusan Menteri Hukum dan HAM RI nomor: AHU-AH-01-03-0012527 untuk PT. PLCM dan nomor: AHU-AH-01-03-0012644 untuk PT. MAS.

Terdakwa bersama-sama saksi YYK dan saksi AK telah menggunakan akta-aktaakta yang dibuat secara tidak benar tersebut untuk menginput perubahan data Perseroan PT. PLCM dan PT. MAS pada Ditjen AHU Kementerian Hukum dan HAM, mengajukan sertifikat clean and clear pada Direktorat Jendral Mineral dan Batubara Kementerian ESDM, dan mengurus legalitas perusahaan. Pihak-pihak yang telah menggunakan akta tersebut untuk menerbitkan legalitas perusahaan, pemberitahuan perubahan data Perseroan oleh Ditjen AHU ataupun untuk mengeluarkan sertifikat clean and clear pada Ditjen minerba tidak mengetahui bahwa akta-akta yang dijadikan kelengkapan tersebut berisikan keterangan yang tidak benar dan dibuat tanpa didukung dengan kelengkapan data yang valid. Namun Terdakwa dengan saksi YYK dan saksi AK tetap mengajukan akta-akta tersebut seolah-olah isinya benar dan tidak dipalsu.

Perbuatan Terdakwa bersama-sama dengan saksi YYK dan saksi AK tersebut telah mengakibatkan PT. CPA selaku pemegang saham terbesar yaitu 90\% pada PT. PLCM dan PT. MAS mengalami kerugian secara materiil yaitu hilangnya seluruh saham PT. CPA pada PT. PLCM dan PT. MAS, selain itu juga kehilangan haknya untuk melakukan perbuatan hukum tidak dapat menginput perubahan hasil Rapat Umum Pemegang Saham PT. PLCM dan PT. MAS pada bulan April 2015 sebagaimana akta PT. PLCM nomor 92 tanggal 21 April 2015 dan Akta PT. MAS nomor 93 tanggal 21 April 2015. Kedua akta tersebut tidak dapat dilaporkan ke Ditjen AHU karena ditolak pada saat menginput ke dalam database dengan alasan ada perubahan pemegang saham dan pengurus dalam akta yang diterbitkan Terdakwa yang tidak diketahui oleh PT. CPA selaku pemegang saham.

Akta Pernyataan Keputusan Rapat Pengalihan Saham PT. PLCM nomor 16 tanggal 30 Januari 2015, akta Pernyataan Keputusan Rapat Pengalihan Saham PT. MAS nomor 18 
tanggal 30 Januari 2015, akta jual beli saham PT. PLCM nomor 17 tanggal 26 Januari 2015 dan akta jual beli saham PT. MAS nomor 19 tanggal 30 Januari 2015 merupakan akta autentik, dimana akta-akta tersebut dibuat oleh Terdakwa selaku Notaris yang merupakan Pejabat umum yang memiliki kewenangan untuk membuat akta-akta tersebut berdasarkan Undang-Undang Jabatan Notaris dan Kitab Undang-Undang Hukum Perdata.

Perbuatan Terdakwa bersama-bersama dengan saksi YYK dan AK merupakan keturutsertaan, masing-masing telah mengetahui dan memiliki maksud yang sama membuat secara tidak benar perubahan akta pendirian PT. PLCM dan PT MAS. Ketika saksi YYK dan saksi AK menandatangani akta-akta tersebut Terdakwa dan saksi YYK serta saksi AK telah mengetahui bahwa isi yang tercantum dalam akta tidak benar yaitu tidak benar ada surat kuasa Direksi kepada P, tidak benar ada Risalah RUPS PT. CPA untuk mengalihkan saham PT. PLCM dan PT. MAS, tidak benar ada peralihan saham dari PT. CPA dan EG kepada saksi YYK, saksi AK, dan saksi S, dan tidak benar P menghadap kepada Terdakwa untuk membuat akta-akta tersebut. Terdapat fakta bahwa untuk membuat secara tidak benar (palsu) akta Notaris tersebut, Terdakwa mendapat imbalan sebesar kurang lebih Rp. 850.000.000. Dalam pertimbangan hakim juga disebutkan bahwa terjadinya tindak pidana tersebut tidak semata-mata oleh tindakan Terdakwa akan tetapi juga atas permintaan dari terdakwa lainnya yang telah di putus sebelumnya yaitu terdakwa AK.

Dikaitkan dengan Undang-Undang Nomor 40 Tahun 2007 Tentang Perseroan Terbatas, berdasarkan isi pada Akta Pernyataan Keputusan Rapat PT. PLCM nomor 16 tanggal 30 Januari 2015 dan akta Pernyataan Keputusan Rapat PT. MAS nomor 18 tanggal 30 Januari 2015 yang memuat keterangan mengenai peralihan saham dari PT. CPA dan EG kepada saksi YYK, saksi AK, dan saksi S dan mencantumkan saksi YYK, saksi AK, dan saksi S sebagai Direksi dan Komisaris Perseroan yang baru, maka kedua Akta tersebut termasuk dalam kategori akta perubahan anggaran dasar Perseroan. Dalam membuat dan menandatangani akta Pernyataan Keputusan Rapat Pengalihan Saham PT. PLCM nomor 16 tanggal 30 Januari 2015 dan akta Pernyataan Keputusan Rapat Pengalihan Saham PT. MAS nomor 18 tanggal 30 Januari 2015 atas permintaan saksi YYK dan saksi AK tanpa adanya asli notulenlrisalah rapat pemegang saham PT. PLCM dan PT. MAS tentang jual beli saham kepada saksi YYK dan surat kuasa Direksi PT. CPA kepada P sebagaimana disebutkan dalam akta. Dari perspektif Undang-Undang Perseroan Terbatas, dalam membuat dan menerbitkan Akta Pernyataan Keputusan Rapat PT. PLCM dan PT. MAS tersebut Terdakwa tidak sesuai dengan ketentuan Pasal 19 ayat (1) dan Pasal 21 ayat (5).

Dari perspektif Undang-Undang Jabatan Notaris, dalam Pasal 39 ayat (1) huruf b Undang-Undang Jabatan Notaris menentukan Penghadap harus memenuhi syarat cakap melakukan perbuatan hukum. Terdakwa membuat Akta Pernyataan Keputusan Rapat Pengalihan Saham PT. PLCM Nomor 16 tanggal 30 Januari 2015 dan Akta Pernyataan Keputusan Rapat Pengalihan Saham PT. MAS nomor 18 tanggal 30 Januari 2015 atas permintaan saksi YYK dan saksi AK tanpa menyerahkan asli risalah 1 notulen RUPS yang menyebutkan yang bersangkutan sebagai penerima kuasa dari pemegang saham PT. PLCM dan PT. MAS untuk menghadap dan menyatakan keputusan RUPS ke dalam Akta Notaris sehingga ssaksi YYK, saksi AK dan saksi S yang menjadi pihak dalam akta tersebut tidak mempunyai kewenangan untuk menghadap dan bertindak melakukan perbuatan hukum dalam akta-akta tersebut namun demikian Terdakwa tetap membuat dan menerbitkan aktaakta tersebut. Sehingga dalam pembuatan akta-akta tersebut tidak sesuai dengan ketentuan Pasal 39 ayat (1) huruf b Undang-Undang Jabatan Notaris. Selanjutnya Pasal 16 ayat (1) huruf e Undang-Undang Jabatan Notaris menentukan Notaris wajib memberikan pelayanan sesuai dengan ketentuan dalam Undang-Undang ini, kecuali ada alasan untuk menolaknya. 
Dalam penjelasannya dimaksud dengan "alasan untuk menolaknya" adalah antara lain alasan yang mengakibatkan Notaris tidak berpihak, seperti salah satu pihak tidak mempunyai kemampuan bertindak untuk melakukan perbuatan, atau hal lain yang tidak dibolehkan oleh undang-undang. Atas permintaan saksi YYK dan AK tanpa menyerahkan notulen atau risalah RUPS PT. PLCM dan PT. MAS, Terdakwa tetap membuatkan akta dan tidak menolaknya. Sehingga dapat dikatakan Terdakwa berpihak kepada saksi YYK dan saksi AK karena meskipun yang bersangkutan tidak memberikan dasar atau bukti sebagai pihak yang mempunyai kemampuan bertindak melakukan perbuatan hukum dalam akta tersebut, Terdakwa tetap membuat dan menerbitkan akta sesuai permintaan yang bersangkutan. Berdasarkan hal tersebut, Terdakwa tidak sesuai ketentuan Pasal 16 ayat (1) huruf e Undang-Undang Jabatan Notaris.

Sesuai Pasal 16 ayat (1) huruf m Undang-Undang Jabatan Notaris menentukan bahwa dalam menjalankan jabatannya Notaris wajib untuk membacakan akta dihadapan penghadap dengan dihadiri oleh paling sedikit 2 (dua) orang saksi dan ditandangani pada saat itu juga oleh penghadap, saksi dan Notaris, namun berdasarkan fakta hukum di persidangan Terdakwa membuat minuta akta pernyataan keputusan rapat pengalihan saham PT. PLCM nomor 16 dan PT. MAS nomor 18 dirumah Terdakwa pada tanggal 30 Januari 2015 yang selanjutnya minuta akta ditandatangani oleh saksi YYK dan saksi AK setelah Terdakwa bacakan isi yang terdapat pada minuta akta di rumah saksi AK bukan dikantor Terdakwa, sedangkan saksi S baru menandatangani minuta akta pada bulan Maret 2015 di sebuah hotel di Jakarta. Penandatangan akta tidak dihadiri oleh 2 (dua) orang saksi sebagaimana disebutkan pada akhir akta dimana pada awal akta memuat keterangan bahwa para pihak menghadap kepada Terdakwa selaku Notaris dan pada akhir akta disebutkan bahwa akta dibuat dan diresmikan dengan dihadiri oleh HH dan ED, namun berdasarkan fakta hukum dalam persidangan pada hari, jam, tanggal, bulan dan tahun tersebut para pihak tidak menghadap kepada Terdakwa di kantor Terdakwa dan saksi-saksi tidak menghadiri pembuatan ataupun peresmian akta. Akta ditandatangani oleh saksi YYK dan saksi AK di rumah saksi AK, bukan di kantor Terdakwa, dan saksi S menandatangani minuta akta pada bulan Maret 2015 di sebuah hotel di Jakarta. Berdasarkan hal tersebut dapat dikatakan bahwa Terdakwa tidak sesuai kewajiban yang ditentukan dalam Pasal 16 ayat (1) huruf $m$ Undang-Undang Jabatan Notaris.

Notaris dalam menjalankan kewenangannya seharusnya bekerja dengan cermat, dan penuh ketelitian, setiap menerbitkan akta harus berdasarkan data-data dan fakta yang senyatanya serta dapat dipertanggungjawabkan, namun Terdakwa membuat dan menandatangani Akta Pernyataan Keputusan Rapat Pengalihan Saham PT. PLCM nomor 16 tanggal 30 Januari 2015 dan Akta Pernyataan Keputusan Rapat Pengalihan Saham PT. MAS nomor 18 tanggal 30 Januari 2015 atas permintaan saksi YYK dan AK tanpa berdasarkan notulen atau risalah rapat pemegang saham PT. PLCM dan PT. MAS tentang jual beli saham kepada saksi YYK, surat kuasa Direksi PT. CPA kepada P dan juga tidak dihadiri oleh para pihak dan saksi-saksi pada hari, jam, tanggal, bulan dan tahun di kantor Terdakwa sebagaimana disebutkan dalam akta. Akta-akta tersebut telah menimbulkan hak bagi saksi YYK, saksi AK, dan saksi S, digunakan seolah-olah isinya benar atau tidak palsu dan mengakibatkan kerugian bagi pihak lain yaitu PT. CPA. Perbuatan Terdakwa tidak sesuai dengan kewajibannya untuk bertindak amanah, jujur, saksama, mandiri, tidak berpihak, dan menjaga kepentingan pihak yang terkait dalam perbuatan hukum sebagaimana Pasal 16 ayat (1) huruf a Undang-Undang Jabatan Notaris.

Sorang Notaris harus memahami dan memenuhi aspek-aspek formal dalam pembuatan akta termasuk syarat-syarat keabsahan akta yang dibuat dan diterbitkannya sehingga dalam menjalankan kewenangannya membuat akta otentik sesuai dengan Undang-Undang Jabatan Notaris dan peraturan perundang-undangan yang berlaku yang 
berkaitan dengan perbuatan hukum dalam akta-akta tersebut, karena apabila Notaris terbukti secara sadar dengan keinsyafan dan direncanakan tidak memenuhi atau mengabaikan aspek-aspek formal pembuatan akta dan akta tersebut dijadikan suatu alat untuk melakukan tindak pidana sehingga menimbulkan kerugian maka Notaris dapat dimintai pertanggungjawaban secara pidana.

Dalam hukum pidana, seseorang yang dinyatakan bersalah harus memenuhi unsurunsur sebagai berikut: ${ }^{44}$

1. Mampu bertanggung jawab

2. Sengaja atau alpa

3. Tidak ada alasan pemaaf

Pertanggungjawaban pidana dimaksudkan untuk menentukan apakah seseorang tersangkalTerdakwa dipertanggungjawabkan atas suatu tindak pidana (crime) yang terjadi atau tidak. Terdakwa akan dipidana atau dibebaskan. Jika ia dipidana harus ternyata bahwa tindakan yang dilakukan itu bersifat melawan hukum dan Terdakwa mampu bertanggung jawab. Kemampuan tersebut memperlihatkan kesalahan dari petindak yang terbentuk kesengajaan atau kealpaan. Tindakan tersebut tercela dan tertuduh menyadari tindakan yang dilakukan tersebut. ${ }^{45}$

Seseorang bertanggungjawab secara hukum atas perbuatan tertentu, ia dapat dikenakan suatu sanksi dalam kasus perbuatannya bertentangan atau berlawanan hukum karena perbuatannya sendiri yang membuat orang tersebut bertanggungjawab. Sanksi dikenakan terhadap pelaku (deliquent) adalah karena perbuatannya sendiri yang membuat orang tersebut harus bertanggungjawab. Tanggung jawab timbul dari adanya tatanan hukum atau aturan hukum yang memberikan kewajiban kepada individu dengan syarat sanksi apabila kewajiban tersebut tidak dilaksanakan. Pertanggungjawaban muncul dari perintah aturan hukum atau Undang-Undang dan sanksi yang diberikan oleh UndangUndang, oleh karena itu pertanggungjwaban yang dilakukan oleh individu merupakan tanggung jawab hukum. Notaris merupakan individu atau subyek hukum yang dibebani kewajiban sebagaimana ketentuan Pasal 16 dan tanggung jawab sebagaimana ketentuan dalam Pasal 65 Undang-Undang Jabatan Notaris. Apabila melanggar kewajiban tersebut maka Notaris akan dikenai sanksi sebagaimana diatur dalam Pasal 16 ayat (11), ayat (12) dan ayat (13) Undang-Undang Jabatan Notaris, sedangkan sanksi pidana tidak diatur dalam Undang-Undang Jabatan Notaris. Namun Notaris dapat jatuhi sanksi pidana apabila terbukti secara sah dan benar memenuhi unsur-unsur tindak pidana dalam Kitab UndangUndang Hukum Pidana.

Dengan telah terpenuhinya semua unsur dalam Pasal 264 ayat (1) Jo Pasal 55 ayat (1) ke 1 Kitab Undang-Undang Hukum Pidana, tidak ditemukan adanya alasan-alasan pembenar maupun pemaaf, dan dengan mempertimbangkan hal kemanusiaan serta hal-hal yang memberatkan dan meringankan Terdakwa, Majelis Hakim Pengadilan Negeri Tangerang dalam putusannya nomor: 1857lPid.Bl20171PN Tng menyatakan Terdakwa terbukti secara sah dan meyakinkan bersalah melakukan tindak pidana turut serta melakukan pemalsuan akta autentik; menjatuhkan pidana oleh karena itu kepada Terdakwa dengan pidana penjara 1 (satu) tahun; menetapkan bahwa pidana penjara tersebut tidak usah dijalankan kecuali dikemudian hari ada putusan hakim yang menentukan lain dikarenakan Terdakwa melakukan suatu tindak pidana sebelum habis masa percobaan 2 (dua) tahun telah melakukan perbuatan yang dapat dipidana, dan menetapkan masa penangkapan dan atau penahanan yang telah dijalani Terdakwa dikurangkan seluruhnya dari pidana yang dijatuhkan. Atas putusan tersebut, Jaksa Penuntut Umum keberatan

\footnotetext{
${ }^{44}$ E.Y. Kanter dan S.R. Sianturi, Asas-Asas Hukum Pidana Di Indonesia Dan Penerapannya, (Jakarta: Storia Grafika, 2018) hlm. 166.

${ }^{45}$ E.Y. Kanter dan S.R. Sianturi, Op.Cit., hlm. 250.
} 
terhadap putusan majelis hakim tingkat pertama yang menjatuhkan hukuman percobaan yang dipandang adil dan cukup membuat Terdakwa berhati-hati membuat akte.

Pertanggungjawaban pidana merupakan pertimbangan hakim yang dilakukan secara normatif dan teologis sebagai wujud asas legalitas dan asas kesalahan. Penelitian yang didasarkan atas kedua asas itu dilakukan oleh hakim secara arif dan bijaksana agar kepastian hukum dan keadilan berjalan bersama. ${ }^{46}$ Dalam proses peradilan hakim harus memberikan kepastian hukum tanpa meninggalkan aspek rasa keadilan dan kemanfaatan. ${ }^{47}$

Setelah mempelajari berkas perkara dan turunan resmi putusan Pengadilan Negeri Tangerang nomor: 18571Pid.B120171PN Tng, Pengadilan Tinggi Banten sependapat dengan Pengadilan tingkat pertama yang menyatakan bahwa Terdakwa terbukti secara sah dan meyakinkan bersalah melakukan tindak pidana "turut serta melakukan pemalsuan aktaakta autentik" dan memori banding penuntut umum tentang pemidanaan (hukuman percobaan) yang dijatuhkan kepada Terdakwa belum memenuhi rasa keadilan dengan pertimbangan bahwa Terdakwa adalah seorang Pejabat Umum atau seorang Notaris yang bertanggung jawab atas sumpah jabatannya dalam pembuatan akta-akta autentik yang pembuktiannya bersifat sempurna, akta Notaris dimaksud harus dapat menjamin kebenaran dan keamanan tentang apa yang menjadi hak seseorang 1 Badan Hukum sesuai dengan yang tercantum dalam akta dimaksud, pidana yang dijatuhkan kepada Terdakwa sebagai seorang Notaris yang membuat akta autentik haruslah seimbang dengan resiko dan kerugian yang diderita korban-korbannya, pidana yang dijatuhkan kepada Terdakwa harus dapat mendidik Terdakwa untuk tidak mengulangi perbuatannya. Selanjutnya Pengadilan Tinggi Banten menguatkan putusan Pengadilan Tingkat Pertama dengan perbaikan tentang pemidanaan yang dijatuhkan kepada Terdakwa yaitu menjatuhkan pidana penjara kepada Terdakwa selama 10 (sepuluh) bulan, menetapkan lamanya Terdakwa dalam tahanan dikurangkan seluruhnya dari pidana yang dijatuhkan, dan memerintahkan agar Terdakwa ditahan.

Pidana penjara selama 10 (sepuluh) bulan yang dijatuhkan Pengadilan Tinggi Banten kepada Terdakwa lebih ringan dibandingkan dengan tuntutan jaksa penuntut umum dalam dakwaan primair yaitu pidana penjara selama 1 (satu) tahun dan 6 (enam) bulan dikurangi masa penahanan sementara, serta ancaman pidana sebagaimana ketentuan dalam Pasal 264 Kitab Undang-Undang Hukum Pidana yaitu 8 (delapan) tahun penjara. Penjatuhan pidana penjara kepada Terdakwa merupakan konsekuensi atau akibat dari tujuan pemidanaan absolut. Namun pemidanaan kepada Terdakwa juga mempunyai tujuan yaitu untuk mendidik Terdakwa agar tidak mengulangi perbuatannya. Sikap Majelis Hakim tersebut berorientasi untuk memperbaiki Terdakwa selaku Notaris ditengah-tengah masyarakat. Sebagaimana dasar-dasar pembenaran pidana yang dikemukakan oleh John Kaplan yaitu untuk menghindari balas dendam (avoidance of blood feuds), adanya pengaruh yang bersifat mendidik (the educationlal effects), dan mempunyai fungsi memelihara perdamaian (the peace keeping function). ${ }^{48}$

\section{PENUTUP}

Kewenangan Notaris untuk membuat Akta Pernyataan mengenai Keputusan Rapat Umum Pemegang Saham Perseroan Terbatas berdasarkan Pasal 15 ayat (1) Undang-Undang Jabatan Notaris dan Pasal 21 ayat (4) dan ayat (5) Undang-Undang Perseroan Terbatas atas

\footnotetext{
${ }^{46}$ Agus Rusianto, Tindak Pidana \& Pertanggungławaban Pidana Tin\}auan Kritis Melalui Konsistensi antara Asas, Teori, dan Penerapannya, Edisi Pertama, (Jakarta: Prenadamedia Group, 2016), hlm. 238.

${ }^{47}$ Margono, Op.Cit., hlm. 116.

${ }^{48}$ Muladi dan Barda Nawawi Arief, Teori-Teori dan Kebi\}akan Pidana, (Bandung: PT. Alumni, 2010), hlm. 20.
} 
permintaan dari pihak yang mempunyai kewenangan bertindak yang diberikan oleh rapat untuk menghadap Notaris dan menyatakan hasil rapat ke dalam akta Notaris berdasarkan bukti asli notulen atau risalah Rapat Umum Pemegang Saham yang dibuat dibawah tangan yang telah ditandatangani dan kelengkapan dokumen sesuai ketentuan anggaran dasar Perseroan dan Undang-Undang Perseroan Terbatas selanjutnya Notaris mengkonstatir secara lahiriah, formal dan materiil dalam bentuk akta dengan berpijak pada aturan, tata cara atau prosedur pembuatan akta sesuai ketentuan Undang-Undang Jabatan Notaris. Pertanggungjawaban Pidana Notaris terhadap Akta Pernyataan Keputusan Rapat yang dibuatnya tidak sesuai dengan Undang-Undang nomor 40 Tahun 2007 tentang Perseroan Terbatas dan Undang-Undang nomor 2 Tahun 2014 tentang perubahan atas Undang-Undang nomor 30 Tahun 2004 tentang Jabatan Notaris dalam perkara pidana sebagaimana putusan Pengadilan Tinggi Banten nomor: 91PID120191PT Btn bahwa perbuatan Terdakwa telah terbukti melanggar Pasal 264 ayat 1 ke-1 jo Pasal 55 ayat 1 ke-1 Kitab Undang-Undang Hukum Pidana. Atas perbuatannya tersebut Terdakwa harus mempertanggungjawabkannya dengan pidana penjara selama 10 (sepuluh) bulan.

Notaris dalam menjalankan kewenangannya membuat akta autentik harus memegang teguh sumpah jabatan, kode etik, dan Undang-Undang Jabatan Notaris. Majelis Pengawas Notaris untuk dapat melakukan sosialisasi atau memberikan sanksi yang tegas kepada Notaris yang melakukan penyimpangan sumpah jabatan, kode etik, dan Undang-Undang Jabatan Notaris berupa teguran sampai dengan pemberhentian.

\section{DAFTAR PUSTAKA}

\section{Buku}

Adjie, Habib, Penafsiran Tematik Hukum Notaris Indonesia Berdasarkan Undang-Undang Nomor 2 Tahun 2014 Tentang Perubahan Atas Undang-Undang Tahun 2004 Tentang Jabatan Notaris, Cetakan Kesatu, Bandung: PT. Refika Aditama, 2015.

Ahmadi, Wiratni, Sari Wahjuni, dan Ahmad S. Djoyosugito, Teknik Pembuatan Akta Notaris, Bandung: Logoz Publishing, 2016.

Arief, Barda Nawawi, Perbandingan Hukum Pidana, Jakarta: Rajawali Pers, 1990.

Asshiddiqie, Jimly dan M. Ali Safa'at, Terjemahan Teori Hans Kelsen Tentang Hukum, Cetakan ke-2, Jakarta: Konstitusi Press, 2012.

Budiono, Herlien, Dasar Teknik Pembuatan Akta Notaris, Bandung: PT. Citra Aditya Bakti, 2017.

Chazawi, Adami dan Ardi Ferdinan, Tindak Pidana Pemalsuan: Tindak Pidana yang Menyerang Kepentingan Hukum Terhadap Kepercayaan Masyarakat Mengenai Kebenaran Isi Tulisan dan Berita yang Disampaikan, Jakarta: PT. RajaGrafindo persada, 2016.

Harahap, M. Yahya, Hukum Perseroan Terbatas, Jakarta: Sinar Grafika, 2016

HR, Ridwan, Hukum Administrasi Negara, Jakarta: Rajagrafindo Persada, 2008.

Ishaq, Metode Penelitian Hukum Penulisan Skripsi, Tesis, Serta Disertasi, Bandung: CV Alfabeta, 2017.

Kanter, E.Y, dan S.R Sianturi, Asas-Asas Hukum Pidana Di Indonesia Dan Penerapannya, Jakarta: Storia Grafika, 2018.

Kelsen, Hans, Pure Theory of Law, Terjemah, Raisul Muttaqien, Teori Hukum Murni: DasarDasar Ilmu Hukum Normatif, Cetakan XVII, Bandung: Nusa Media, 2015.

Kie, Tan Thong, Studi Notariat \& Serba-Serbi Praktek Notaris, Jakarta: PT. Ichtiar Baru Van Hoeve, 2011. 
Margono, Asas Keadilan Kemanfaatan \& Kepastian Hukum Dalam Putusan Hakim, Jakarta: Sinar Grafika, 2020.

Mertokusumo, Sudikno, Mengenal Hukum Suatu Pengantar, Yogyakarta: Liberty, 2003.

Muhammad, Abdulkadir, Hukum Perusahaan Indonesia, Bandung: Citra Aditya Bakti, 2010.

Muladi dan Barda Nawawi Arief, Teori-Teori dan Kebilakan Pidana, Bandung: PT. Alumni, 2010.

Notodisoerjo, R. Soegondo, Hukum Notariat di Indonesia Suatu Penłelasan, Jakarta: Raja Grafindo Persada, 1993.

Rahardjo, Satjipto, Hukum Dalam Jagat Ketertiban: Bacaan Mahasiswa Program Doktor Ilmu Hukum Universitas Diponegoro, Jakarta: UKI Press, 2006.

Rusianto, Agus, Tindak Pidana \& Pertanggungławaban Pidana Tin\}auan Kritis Melalui Konsistensi antara Asas, Teori, dan Penerapannya, Edisi Pertama, Jakarta: Prenadamedia Group, 2016.

Salim, HS, dan Erlies Septiana Nurbani, Penerapan Teori Hukum Pada Penelitian Tesis dan Disertasi, Jakarta: PT. RajaGrafindo Persada, 2018.

Syahrani, Riduan, Rangkuman Intisari Ilmu Hukum, Bandung: Citra Aditya Bakti, 1999.

Sjaifurrachman dan Habib Adjie, Aspek Pertanggungławaban Notaris dalam Pembuatan Akta, Bandung: CV Mandar Maju, 2011.

Sulhan, Irwansyah Lubis dan Anhar Syahnel, Profesi Notaris Dan Pelabat Pembuat Akta Tanah (Panduan Praktis Dan Mudah Taat Hukum), Jakarta: Mitra Wacana Media, 2018.

Soekanto, Soerjono dan Sri Mamudji, Penelitian Hukum Normatif Sebagai Tin\}auan Singkat, Jakarta: Rajagrafindo, 2010.

\section{Perundang-Undangan}

Indonesia, Undang-Undang Republik Indonesia Tentang Perubahan atas UndangUndang Nomor 30 Tahun 2004 tentang Jabatan Notaris, UU No. 2 LN Tahun 2014 No. 3, TLN No. 5491.

, Undang-Undang Republik Indonesia Tentang Perseroan Terbatas, UU No. 40 LN Tahun 2007, No. 106, TLN No. 4756.

Kitab Undang-Undang Hukum Pidana [Wetboek van Straftrecht], Diterjemahkan oleh Moeljatno, Jakarta: Pradnya Paramita, 1976.

\section{Wawancara}

Wawancara dengan Purwanto, 27 November 2020., Pukul 10.00 WIB. 